\title{
Helicobacter pylori eradication therapy to prevent gastric cancer in healthy asymptomatic infected individuals: systematic review and meta-analysis of randomised controlled trials
}

\author{
(c) $\underset{1}{(1)(8)}$ OPEN ACCESS
}

\author{
Alexander C Ford associate professor and honorary consultant gastroenterologist ${ }^{12}$, David Forman \\ head of section ${ }^{3}$, Richard H Hunt professor of gastroenterology ${ }^{4}$, Yuhong Yuan research associate ${ }^{4}$, \\ Paul Moayyedi director of Gastroenterology Division ${ }^{4}$
}

${ }^{1}$ Leeds Gastroenterology Institute, St James's University Hospital, Leeds LS9 7TF, UK; ${ }^{2}$ Leeds Institute of Biomedical and Clinical Sciences, University of Leeds, Leeds, UK; ${ }^{3}$ Cancer Information Section, International Agency for Research on Cancer, Lyon, France; ${ }^{4}$ Farncombe Family Digestive Health Research Institute, Gastroenterology Division, McMaster University, Health Sciences Center, Hamilton, Ontario, Canada

\begin{abstract}
Objectives To determine whether searching for Helicobacter pylori and treating with eradication therapy leads to a reduction in incidence of gastric cancer among healthy asymptomatic infected individuals.

Design Systematic review and meta-analysis of randomised controlled trials.

Data sources Medline, Embase, and the Cochrane central register of controlled trials were searched through to December 2013. Conference proceedings between 2001 and 2013 were hand searched. A recursive search was performed with bibliographies of relevant studies. There were no language restrictions.

Eligibility criteria for selecting studies Randomised controlled trials examining the effect of at least seven days of eradication therapy on subsequent occurrence of gastric cancer in adults who tested positive for Helicobacter pylori but otherwise healthy and asymptomatic were eligible. The control arm had to receive placebo or no treatment. Subjects had to be followed for $\geq 2$ years.

Main outcome measures Primary outcome, defined a priori, was the effect of eradication therapy on the subsequent occurrence of gastric cancer expressed as a relative risk of gastric cancer with $95 \%$ confidence intervals.

Results The search strategy identified 1560 citations, of which six individual randomised controlled trials were eligible. Fifty one (1.6\%) gastric cancers occurred among 3294 individuals who received eradication therapy versus $76(2.4 \%)$ in 3203 control subjects (relative risk $0.66,95 \%$ confidence interval 0.46 to 0.95 ), with no heterogeneity
\end{abstract}

between studies $\left(I^{2}=0 \%, P=0.60\right)$. If the benefit of eradication therapy was assumed to persist lifelong the number needed to treat was as low as 15 for Chinese men and as high as 245 for US women.

Conclusions These data provide limited, moderate quality evidence that searching for and eradicating $\mathrm{H}$ pylori reduces the incidence of gastric cancer in healthy asymptomatic infected Asian individuals, but these data cannot necessarily be extrapolated to other populations.

\section{Introduction}

Gastric cancer is the third commonest cause of cancer death worldwide, with almost three quarters of a million deaths annually. ${ }^{1}$ Despite a declining incidence in many countries in the developed world, there is an increase in global mortality from the disease because of population growth and increasing longevity in developing countries. ${ }^{2}$

Infection with Helicobacter pylori ${ }^{3}$ causes chronic gastritis, ${ }^{4}$ which can lead to gastric atrophy and intestinal metaplasia.

These are the main histological precursors to gastric cancer, and it is therefore plausible that $H$ pylori infection may cause gastric cancer. ${ }^{5}$ A systematic review of nested case-control studies confirmed that individuals who tested positive for $\mathrm{H}$ pylori were between three and six times more likely to develop gastric cancer compared with uninfected controls. ${ }^{7-9}$ Such data led the International Agency for Research on Cancer to conclude that H pylori was a class I human carcinogen..$^{10}$ A policy of searching for and eradicating $\mathrm{H}$ pylori among healthy asymptomatic individuals in populations at high risk of gastric cancer could 
theoretically lead to a reduction in the incidence of gastric cancer. ${ }^{11}$ However, healthcare providers have not considered this policy seriously, and are unlikely to do so until randomised controlled trials show such a strategy to be effective.

The only fully published systematic review of randomised controlled trials reported a significant reduction in the relative risk of developing gastric cancer with $H$ pylori eradication therapy, compared with placebo. ${ }^{12}$ However, the authors included data from the same trial twice, at two different follow-up points. ${ }^{13}$ When data from only one or other of these follow-up points were included the effect was no longer statistically significant. Given that it is five years since the publication of this meta-analysis, the possibility that there may now be more published trials, as well as longer duration of follow-up in the existing trials, led us to re-examine this issue. Our hypothesis was that there may now be a significant effect of $\mathrm{H}$ pylori eradication therapy in preventing gastric cancer in healthy asymptomatic infected individuals. This is a Cochrane Collaboration systematic review, with the protocol peer reviewed, published, and available online. ${ }^{14}$

\section{Methods}

\section{Search strategy and study selection}

A search of the medical literature was conducted using Medline (1946 to December 2013), Embase (1947 to December 2013), and the Cochrane central register of controlled trials. Randomised controlled trials examining the effect of eradication therapy on subsequent occurrence of gastric cancer in $H$ pylori-positive adults ( $>16$ years old) who were otherwise healthy and who were not consulting with gastrointestinal symptoms were eligible for inclusion (box 1).

The literature search used is detailed in appendix 1 of the supplementary data. There were no language restrictions, and abstracts of the papers identified by the initial search were evaluated by the lead reviewer for appropriateness to the study question. Abstract books of conference proceedings between 2001 and 2013 were hand searched to identify potentially eligible studies published only in abstract form. Authors of trial reports published only as abstracts were contacted and asked to contribute full datasets or completed papers. The bibliographies of all identified relevant studies were used to perform a recursive search of the literature. Articles were assessed independently by two investigators using pre-designed eligibility forms according to the eligibility criteria, defined prospectively. Any disagreement between investigators was resolved by consensus.

For fully published studies that randomised healthy, asymptomatic, $H$ pylori-positive individuals to receive eradication therapy or either placebo or no treatment, but which did not report data concerning subsequent occurrence of gastric cancer, we contacted the first or senior author in order to maximise our chances of identifying eligible studies. We also contacted authors of all eligible studies that did report subsequent occurrence of gastric cancer, in order to obtain data at the most recent point of follow-up. Finally, where multiple articles for a single study were found, we contacted the first or senior author in order to ensure that only data from the latest publication from each eligible study were extracted.

\section{Outcome assessment}

The primary outcome assessed was the effect of $H$ pylori eradication therapy, compared with placebo or no treatment, on the subsequent occurrence of gastric cancer. Secondary outcomes included the effect of eradication therapy on subsequent occurrence of oesophageal cancer, effect on gastric cancer related mortality, effect on all cause mortality, and adverse events arising from eradication therapy.

\section{Data extraction}

All data were extracted independently by two investigators as dichotomous outcomes (presence or absence of gastric cancer). In addition, the following clinical data were extracted for each trial: geographical location, country of origin, number of centres, method used to confirm $H$ pylori infection, type of $H$ pylori eradication regimen used (including dose and schedule of individual drugs within it), duration of treatment, eradication rate, duration of follow-up, subsequent occurrence of oesophageal cancer, mortality from gastric cancer, mortality from other causes, and total number of adverse events reported. As some of the trials we identified performed upper gastrointestinal endoscopy and obtained gastric biopsy specimens in all recruited subjects, we were able to obtain the number of individuals in these trials with pre-neoplastic lesions at baseline (defined as presence of gastric atrophy, intestinal metaplasia, or dysplasia).

Data were extracted as a modified intention-to-treat analysis. In this, we excluded from the analysis individuals found to be ineligible after randomisation and those who did not receive the intervention to which they were assigned; also, because of the relatively rare nature of the outcome of interest, we assumed that all subjects lost to follow-up had not developed gastric cancer but kept them in the denominator for the study. This was particularly important given that the shortest duration of follow-up in the studies we identified was $\geq 4$ years, and so numbers of drop-outs were relatively high. We also performed a complete case analysis, as a sensitivity analysis, where all participants for whom data were missing or unavailable were excluded from the analysis altogether. ${ }^{15}$

We performed a further two sensitivity analyses with missing data imputed using two assumptions. In the first of these, we assumed that the incidence of gastric cancer for missing participants in either trial arms were the same as that observed in the trial control arms. In the second of these, which was the worst case scenario, we assumed that the incidences of gastric cancer for missing participants in the H pylori eradication arms were the same as that observed in the trial control arms, but there were no new gastric cancer cases in the control arms among those with missing data.

\section{Assessment of risk of bias}

Risk of bias assessment was performed independently by two investigators, with disagreements resolved by discussion. Risk of bias was assessed as described in the Cochrane handbook ${ }^{16}$ by recording the method used to generate the randomisation schedule and conceal allocation; whether blinding was implemented for participants, staff, and outcome assessment; what proportion of subjects completed follow-up; and whether there was evidence of selective reporting of outcomes.

\section{Data synthesis and statistical analysis}

Data were pooled using a random effects model ${ }^{17}$ to give a more conservative estimate of the effect of $H$ pylori eradication therapy on the subsequent occurrence of gastric cancer, allowing for any heterogeneity between studies. The impact of eradication therapy, compared with placebo or no treatment, was expressed as a relative risk of occurrence of gastric cancer with $95 \%$ confidence intervals. Adverse events data were also summarised 


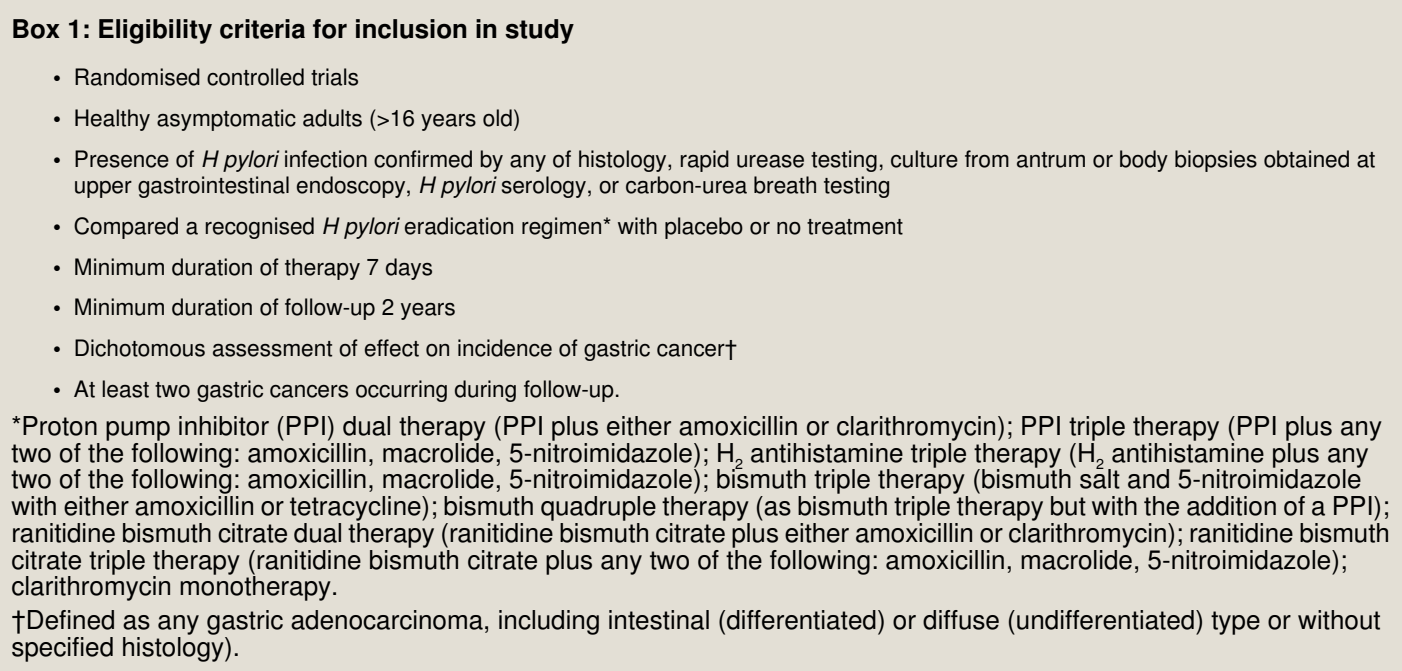

with relative risks. The number needed to treat, with a $95 \%$ confidence interval, was calculated using the formula:

Number needed to treat $=1 /($ assumed control risk $\times(1-$ relative risk))

where the assumed control risk varies according to the population studied and the duration of follow-up. We estimated the assumed control risk from the lifetime risk of gastric cancer in Japanese, Chinese, US, and UK men and women, published by the International Agency for Research on Cancer. ${ }^{18}$ This assumes that any benefit of $H$ pylori eradication persists beyond the duration of follow-up of trials. A more conservative estimate of the number needed to treat was made from the assumed control risk derived from the meta-analysis.

Heterogeneity between studies was assessed using both the $\mathrm{I}^{2}$ statistic with a cut off of $\geq 50 \%$, and the $\chi^{2}$ test with a $P$ value $<0.10$ used to define a significant degree of heterogeneity. ${ }^{19}$

Where the degree of statistical heterogeneity was greater than this between trial results, possible explanations were investigated using subgroup analyses according to the eradication regimen used, geographical location, and risk of bias of included trials. We compared individual relative risks between these analyses using the Cochran Q statistic. These were exploratory analyses only and may explain some of the observed variability, but the results should be interpreted with caution.

Review Manager version 5.1.4 (RevMan for Windows 2008, the Nordic Cochrane Centre, Copenhagen, Denmark) and StatsDirect version 2.7.7 (StatsDirect, Sale, Cheshire, England) were used to generate Forest plots of pooled relative risks for primary and secondary outcomes with $95 \%$ confidence intervals, as well as funnel plots. The latter were assessed for evidence of asymmetry and therefore possible publication bias or other small study effects, using the Egger test ${ }^{20}$ if there were $\geq 10$ eligible studies included in the meta-analysis, in line with recent recommendations. ${ }^{21}$

\section{Results}

The search strategy identified 1560 citations. The titles and abstracts were reviewed, and 32 articles that were thought to be potentially eligible for inclusion were retrieved and evaluated (fig $1 \Downarrow$ ). Of these, six individual randomised controlled trials, reported in 14 separate publications, ${ }^{22-35}$ compared $H$ pylori eradication therapy with placebo or no treatment and provided data on subsequent occurrence of gastric cancer, and therefore appeared to be eligible. However, five of these were redundant publications with no new information reported and were therefore also excluded, ${ }^{29-31} 3334$ leaving nine publications from the six trials that reported extractable unique data. ${ }^{22-28} 3235$

Of the remaining 18 articles we identified, six were not randomised controlled trials, ${ }^{36-41}$ three were trials comparing the interventions of interest but did not report any gastric cancer data, ${ }^{42-44}$ and two were trials with insufficient incident gastric cancers occurring during follow-up to meet our inclusion criteria. ${ }^{45}{ }^{46}$ In the latter five studies, the reason for exclusion was confirmed after contact with the authors. In addition, four articles were duplicate publications of articles already classed as ineligible. ${ }^{47-50}$ Two studies were trials conducted among patients undergoing endoscopic mucosal resection of early gastric cancer ${ }^{51}{ }^{52}$ rather than healthy asymptomatic infected subjects, and one did not compare the interventions of interest. ${ }^{53}$

Table $1 \Downarrow$ lists the characteristics of eligible and included studies, including demographic data of participants, methods used to ascertain gastric cancer incidence, and $\mathrm{H}$ pylori eradication rates (reported using a true intention-to-treat analysis with all drop-outs assumed to have failed eradication therapy). Three of the trials, reported in five separate publications, were of factorial design with some participants also randomised to receive vitamins, antioxidants, or celecoxib (appendix 2 of the supplementary data). ${ }^{22} 25263235$ The majority of trials were conducted in Japan or China, with only one study being conducted outside this region, among a population at high risk of gastric cancer in Colombia. ${ }^{22}{ }^{35}$ The longest duration of follow-up in the studies we identified was 14.7 years,${ }^{26}$ and the shortest duration was $\geq 4$ years. ${ }^{23}$ Three trials were at low risk of bias, ${ }^{24-2632}$ one trial was at unclear risk, ${ }^{23}$ and two trials were at high risk of bias. Of the two trials at high risk of bias, one was because there was no placebo comparator for the active eradication therapy, so that this part of the trial was unblinded ${ }^{22}{ }^{35}$; and the other was due to inconsistencies in data reporting at the two points of follow-up, with 10 gastric cancers reported at five years, compared with nine at 10 years. ${ }^{27}{ }^{28} \mathrm{In}$ the case of this latter trial, we used data from the 10 year follow-up in our primary analysis, but substituted the five year data in a sensitivity analysis.

\section{Effect of $H$ pylori eradication therapy on subsequent occurrence of gastric cancer}

When data were pooled from the six trials at the last point of follow-up in our primary analysis (including all arms in the two trials of factorial design that also contained vitamins and antioxidants ${ }^{22} 263235$ and the 10 year follow-up data from $\mathrm{Zhou}^{27}$ ), 
$51(1.6 \%)$ gastric cancers had occurred among 3294 healthy asymptomatic infected subjects who received $H$ pylori eradication therapy compared with 76 (2.4\%) cancers in 3203 individuals allocated to placebo or no treatment. There was only one case of gastric MALT lymphoma reported in the six studies, ${ }^{23}$ but this was not included in the analyses. The relative risk of subsequent occurrence of gastric cancer with eradication therapy versus placebo or no treatment was $0.66(95 \%$

confidence interval 0.46 to 0.95 ) (fig $2 \Downarrow$ ), with no heterogeneity between studies $\left(\mathrm{I}^{2}=0 \%, \mathrm{P}=0.60\right)$. There were insufficient trials to assess for evidence of funnel plot asymmetry. The number needed to treat, using data from the meta-analysis with an assumed control risk of $2.4 \%$, was 124 (95\% confidence interval 78 to 843). However, if we assume that the benefit of $H$ pylori eradication persists lifelong, then the number needed to treat is as low as 15 for Chinese men and as high as 245 for US women (table $2 \Downarrow$ ).

We performed several sensitivity analyses when pooling data from these six trials (table $3 \Downarrow$ ). None of these analyses changed the statistical significance of the relative risk of subsequent gastric cancer with eradication therapy compared with placebo or no treatment, there was no heterogeneity between studies in any of these analyses, and in most cases the effect sizes were almost identical. We also performed pre-specified subgroup analyses (table $4 \Downarrow$ ). Importantly, when only Asian studies or those at low risk of bias were included in the analysis the relative risk remained statistically significant, with no heterogeneity between studies in either of these analyses.

We performed further analyses according to the presence or absence of pre-neoplastic lesions at baseline, and according to co-administration of antioxidants and vitamins. There was no significant benefit of $H$ pylori eradication therapy in preventing subsequent occurrence of gastric cancer when only those either with or without pre-neoplastic lesions at baseline were considered in the analysis (fig $3 \Downarrow$ ). When only subjects receiving $H$ pylori eradication therapy were considered in the analysis, there was no significant reduction in the relative risk of subsequent gastric cancer $(0.82,95 \%$ confidence interval 0.46 to 1.45 ) (fig $4 \Downarrow)$, with no heterogeneity between studies $\left(I^{2}=13 \%\right.$, $\mathrm{P}=0.33$ ). However, when those receiving eradication therapy in combination with antioxidants or vitamins were considered in the analysis the relative risk was significantly lower with eradication therapy $(0.52,0.31$ to 0.87$)$.

\section{Effect of $H$ pylori eradication therapy on subsequent occurrence of oesophageal cancer}

Only one of the studies we identified reported these data. ${ }^{24}$ There were two $(0.2 \%)$ individuals who developed oesophageal cancer among 817 healthy asymptomatic infected subjects assigned to eradication therapy, compared with one $(0.1 \%)$ of 813 allocated to placebo $(\mathrm{P}=0.57)$. All three cases were squamous cell cancers.

\section{Effect of $H$ pylori eradication therapy on subsequent mortality from gastric cancer}

There were three studies, containing 4475 subjects, which provided data on mortality from gastric cancer. ${ }^{24} 26{ }^{28}$ Follow-up in these three trials ranged from five years to 14.7 years. Overall, there were 24 deaths $(1.1 \%)$ from gastric cancer among 2242 healthy asymptomatic infected individuals randomised to eradication therapy, compared with 36 (1.6\%) deaths in 2233 participants allocated to placebo. The relative risk of death from gastric cancer with eradication therapy compared with placebo was 0.67 (95\% confidence interval 0.40 to 1.11 ) (fig $5 \Downarrow$ ), with no heterogeneity between studies $\left(\mathrm{I}^{2}=0 \%, \mathrm{P}=0.90\right)$.

\section{Effect of $H$ pylori eradication therapy on subsequent all cause mortality}

There were four studies that reported all cause mortality among 5253 recruited individuals according to treatment allocation. ${ }^{22}{ }^{24-26}$ Follow-up in these four trials ranged from six years to 14.7 years. In total, $192(7.3 \%)$ of 2639 healthy asymptomatic infected subjects receiving eradication therapy were dead at last point of follow-up, compared with 175 (6.7\%) of 2614 individuals receiving placebo or no treatment. The relative risk of death from any cause at last point of follow-up with eradication therapy compared with placebo or no treatment was 1.09 ( 0.86 to 1.38 ) (fig $6 \Downarrow)$, with no heterogeneity between studies $\left(\mathrm{I}^{2}=6 \%, \mathrm{P}=0.36\right)$.

\section{Adverse events}

Only one of the studies reported individual adverse events data with eradication therapy compared with placebo or no treatment, in a separate paper. ${ }^{54}$ There was no statistically significant difference in the incidence of adverse events with eradication therapy, with the exception of skin rash, which occurred in $3.1 \%$ of those receiving eradication therapy compared with $0.1 \%$ of those allocated placebo. Another study mentioned that side effects were monitored closely and none of any clinical importance was detected. ${ }^{22}$

\section{Discussion}

\section{Principal findings}

This systematic review and meta-analysis suggests that searching for and eradicating $H$ pylori infection reduces the subsequent incidence of gastric cancer in healthy asymptomatic infected individuals. This observation was robust through most of the sensitivity analyses we performed. The number needed to treat varied according to the risk of cancer in the population under study, but we estimated that it could be as low as 15 in $H$ pylori-positive men living in a region with a high risk of gastric cancer, such as China or Japan, compared with almost 250 in infected women from a low risk region such as the US.

\section{Strengths and limitations of study}

Strengths of this study include a contemporaneous and exhaustive search strategy, allowing us to pool data from over 6000 subjects in our primary analysis. We contacted authors of all included studies, as well as some excluded studies, in order to obtain data from the last point of follow-up, as well as to ensure we had not missed potentially eligible trials, or included data from the same study at two different points of follow-up.

There are limitations of this study because of characteristics of the published literature identified. Only three of the trials we identified were at low risk of bias. ${ }^{24-26} 32$ In addition, because of the factorial design of some of the trials, it is difficult to determine whether the reduction in relative risk of subsequent gastric cancer was due to $H$ pylori eradication therapy alone. The beneficial effect seemed to be more pronounced in the two studies that co-administered antioxidants and vitamins to participants, but it should be noted that one of these contained the majority of gastric cancers and had the longest duration of follow-up. As all but one study was conducted in East Asia, it is also not possible to assess the effect of searching for and eradicating $H$ pylori in Western populations. The eradication regimens used varied considerably between the individual trials, 
although this reflects the fact that several of these studies were designed before the widespread adoption of proton pump inhibitor triple therapy, which was first described in $1994^{55}$ as the gold standard for $H$ pylori eradication. Finally, individual adverse events data were not reported by many of the trials we identified, and we were not able to assess the balance of benefits and harms if searching for and eradicating $H$ pylori infection were to be adopted in the general population.

\section{Comparison with other studies}

In models of the natural course of gastric cancer a chronic inflammatory response in the gastric mucosa leads to a superficial gastritis, which progresses on to gastric atrophy, and ultimately intestinal metaplasia. ${ }^{56}$ Both atrophy and intestinal metaplasia have been proposed as potential precursor lesions of gastric cancer, with atypical changes then taking place within the gastric mucosa, resulting in dysplasia. In support of this model is a study of individuals from communities in Colombia, with differing risks of gastric cancer, in which less than a quarter of individuals from the highest risk region had an entirely normal gastric mucosa by the age of 25 years. ${ }^{56}$ One of the trials in this meta-analysis demonstrated a significant reduction in the risk of subsequent gastric cancer with eradication therapy only in those without pre-neoplastic changes at baseline ${ }^{24}$ suggesting that there may be a "point of no return" beyond which cancer prevention by eradication of $H$ pylori infection is no longer possible.

Although these data suggest that searching for and eradicating $H$ pylori may reduce the incidence of gastric cancer in healthy asymptomatic infected individuals, the $95 \%$ confidence intervals are wide and the result is heavily dependent on one study. ${ }^{26}$ However, other evidence supports these data. There are two open label trials that have evaluated the efficacy of $\mathrm{H}$ pylor $i$ eradication versus no therapy in preventing further gastric neoplasia in patients who have had an endoscopic mucosal resection of gastric cancer. ${ }^{51}{ }^{52}$ These studies suggest that $H$ pylori eradication can reduce the future incidence of a metachronous cancer.

Further support is provided by a recent observational study from Matsu Island in Taiwan, ${ }^{57}$ where an approach of searching for and eradicating $H$ pylori was adopted in 2004. In the following four years $H$ pylori prevalence among participants fell from $63 \%$ at baseline to less than $14 \%$ in 2008 , and the five year average incidence of gastric cancer declined from 40.3/100 000 person years to 30.4 , yielding a rate ratio of $0.75(95 \%$ confidence interval 0.37 to 1.52 ), at a time when gastric cancer incidence rates in the rest of Taiwan remained static.

A recent systematic review of cost effectiveness studies suggested this strategy was cost effective. ${ }^{58}$ Trials from Western countries demonstrate that searching for and eradicating $\mathrm{H} \mathrm{pylori}$ leads to a reduction in the community incidence of dyspepsia, ${ }^{43} 48$ as well as the costs of managing the condition. ${ }^{47-49} 59$ The potential benefits of adopting such a programme are therefore attractive. However, despite accumulating evidence, only guidelines from the Asian-Pacific gastric cancer consensus have made a clear recommendation with respect to searching for and eradicating $H$ pylori in populations at high risk of gastric cancer. ${ }^{60}$

\section{Conclusions and policy implications}

These data provide limited, moderate quality, evidence that searching for and eradicating $H$ pylori can reduce the incidence of gastric cancer in healthy asymptomatic infected individuals. As the only trial conducted in a non-Asian population failed to show any benefit of such an approach, these data should not be extrapolated to populations outside Asia. Given that any programmes based on such an intervention will involve healthy subjects, there needs to be greater confidence in the estimate of effect and more information on any potential harms of $\mathrm{H}$ pylori eradication before such a strategy can be advocated as a means of preventing gastric cancer. It seems likely that the benefit of searching for and eradicating $\mathrm{H}$ pylori in healthy asymptomatic individuals will outweigh any potential harms, especially in populations at high risk of gastric cancer. However, results from further trials in different populations are urgently needed to extend the evidence base. While there are some trials in progress, countries that wish to develop public health measures to control gastric cancer should consider appropriate randomised designs in implementation (for example, cluster methodologies or comparisons of early against late adopters) in order to add to our knowledge.

Contributors: All authors conceived and drafted the study, and analysed and interpreted the data. ACF drafted the manuscript, and all authors approved the final draft of the manuscript. All authors had full access to all of the data (including statistical reports and tables) in the study and can take responsibility for the integrity of the data and the accuracy of the data analysis.

\section{Funding: None.}

Competing interests: All authors have completed the Unified Competing Interest form at www.icmje.org/coi_disclosure.pdf (available on request from the corresponding author) and declare that they have no relationships with companies that might have an interest in the submitted work in the previous 3 years; their spouses, partners, or children have no financial relationships that may be relevant to the submitted work; and they have no non-financial interests that may be relevant to the submitted work."

Data sharing: No additional data available.

Transparency: ACF (the manuscript's guarantor) affirms that the manuscript is an honest, accurate, and transparent account of the study being reported; that no important aspects of the study have been omitted; and that any discrepancies from the study as planned (and, if relevant, registered) have been explained.

1 Ferlay J, Soerjomataram I, Ervik M, Dikshit R, Eser S, Mathers C, et al. GLOBOCAN 2012, version 1.0: Cancer incidence and mortality worldwide. IARC CancerBase No 11 . International Agency for Research on Cancer; 2013. Available from http:globocan.iarc. fr.

2 Bray F, Jemal A, Grey N, Ferlay J, Forman D. Global cancer transitions according to the Human Development Index (2008-2030): a population-based study. Lancet Oncol 2012;13:790-801.

3 Warren JR, Marshall BJ. Unidentified curved bacilli on gastric epithelium in active chronic gastritis. Lancet 1983;321:1273-5.

4 Marshall BJ, Armstrong JA, McGechie DB, Glancy RJ. Attempt to fulfill Koch's postulates for pyloric Campylobacter. Med J Aust 1985;142:436-9.

5 Correa P. The gastric precancerous process. Cancer Surv 1983;2:437-50.

6 Correa P, Haenszel W, Cuello C, Tannenbaum S, Archer M. A model for gastric cancer epidemiology. Lancet 1975;306:58-60

7 Nomura A, Stemmerman GN, Chyou P-H, Kato I, Perez-Perez GI, Blaser MJ. Helicobacter pylori infection and gastric carcinoma among Japanese Americans in Hawaii. N Engl J Med 1991;325:1132-6.

8 Parsonnet J, Friedman GD, Vandersteen DP, Chang $\mathrm{Y}$, Vogelman JH, Orentreich N, et al. Helicobacter pylori infection and the risk of gastric carcinoma. N Engl J Med 1991;325:1127-31.

9 Forman D, Newell DG, Fullerton F, Yarnell JWG, Stacey AR, Wald N, et al. Association between infection with Helicobacter pylori and risk of gastric cancer: Evidence from a prospective investigation. BMJ 1991;302:1302-5.

10 International Agency for Research on Cancer. Schistosomes, liver flukes and Helicobacter pylori. IARC Monogr Eval Carcinog Risks Hum 1994;61:177-241.

11 Parsonnet J, Harris RA, Hack HM, Owens DK. Modelling cost-effectiveness of Helicobacter pylori screening to prevent gastric cancer: A mandate for clinical trials. Lancet 1996;348:150-4.

12 Fuccio L, Zagari RM, Eusebi LH, Laterza L, Cennamo V, Ceroni L, et al. Meta-analysis: Can Helicobacter pylori eradication treatment reduce the risk for gastric cancer? Ann Intern Med 2009;151:121-8.

13 Ford AC, Moayyedi P. Redundant data in the meta-analysis on Helicobacter pylori eradication. Ann Intern Med 2009;151:513.

14 Moayyedi P, Hunt R, Forman D. Helicobacter pylori eradication for the prevention of gastric neoplasia. Cochrane Database Syst Rev 2006;(1):CD005583. 


\section{What is already known on this topic}

Gastric cancer is causally related to infection with Helicobacter pylori

Searching for and eradicating $\mathrm{H}$ pylori could theoretically reduce the incidence of gastric cancer, but evidence is conflicting

\section{What this study adds}

Gastric cancer incidence was significantly lower in healthy asymptomatic infected individuals randomised to receive eradication therapy compared with those allocated to placebo or no treatment

The number needed to treat to prevent one gastric cancer was 124 overall, but was as low as 15 for Chinese men and as high as 245 for US women

15 AkI EA, Johnston BC, Alonso-Coello P, Neumann I, Ebrahim S, Briel M, et al. Addressing dichotomous data for participants excluded from trial analysis: A guide for systematic reviewers. PLoS One 2013;8:e57132.

16 Higgins JPT, Green S. Cochrane handbook for systematic reviews of interventions. Version 5.0.2. 2009. www.cochrane-handbook.org.

17 DerSimonian R, Laird N. Meta-analysis in clinical trials. Control Clin Trials 1986;7:177-88.

18 International Agency for Research on Cancer. GLOBOCAN 2008. Estimated cancer incidence, mortality, prevalence and disability-adjusted life years (DALYs) worldwide in 2008. 2008. http://globocan.iarc.fr/.

19 Higgins JPT, Thompson SG, Deeks JJ, Altman DG. Measuring inconsistency in meta-analyses. BMJ 2003;327:557-60.

20 Egger M, Davey-Smith G, Schneider M, Minder C. Bias in meta-analysis detected by a simple, graphical test. BMJ 1997;315:629-34.

21 Sterne JA, Sutton AJ, loannidis JP, Terrin N, Jones DR, Lau J, et al. Recommendations for examining and interpreting funnel plot asymmetry in meta-analyses of randomised controlled trials. BMJ 2011;343:d4002.

22 Correa P, Fontham ETH, Bravo JC, Bravo LE, Ruiz B, Zarama G, et al. Chemoprevention of gastric dysplasia: Randomized trial of antioxidant supplements and anti-Helicobacter pylori therapy. J Natl Cancer Inst 2000;92:1881-8.

23 Saito D, Boku N, Fujioka T, Fukuda Y, Matsushima Y, Sakaki N, et al. Impact of H. pylor eradication on gastric cancer prevention: Endoscopic results of the Japanese intervention trial (JITHP-Study): A randomized multi-center trial. Gastroenterology 2005;128 (suppl 2):A4.

24 Wong BCY, Lam SK, Wong WM, Chen JS, Zheng TT, Feng RE, et al. Helicobacter pylori eradication to prevent gastric cancer in a high-risk region of China: A randomized controlled trial. JAMA 2004;291:187-94.

25 Wong BCY, Zhang L, Ma J-L, Pan K-F, Li J-Y, Shen L, et al. Effects of selective COX-2 inhibition and Helicobacter pylori eradication on precancerous gastric lesions. Gut 2012;61:812-8.

26 Ma J-L, Zhang L, Brown LM, Li J-Y, Shen L, Pan K-F, et al. Fifteen-year effects of Helicobacter pylori, garlic, and vitamin treatments on gastric cancer incidence and mortality. J Natl Cancer Inst 2012;104:488-92.

27 Zhou L. Ten-year follow-up study on the incidence of gastric cancer and the pathological changes of gastric mucosa after H. pylori eradication in China. Gastroenterology 2008;134(suppl 1):A233

28 Leung WK, Lin S-R, Ching JYL, To K-F, Ng EKW, Chan FKL, et al. Factors predicting progression of gastric intestinal metaplasia: Results of a randomised trial on Helicobacter pylori eradication. Gut 2004;53:1244-9.

29 Mera R, Fontham ETH, Bravo LE, Bravo JC, Piazuelo MB, Camargo MC, et al. Long-term follow-up of patients treated for Helicobacter pylori infection. Gut 2005;54:1536-40.

30 Ruiz B, Garay J, Correa P, Fontham ETH, Bravo JC, Bravo LE, et al. Morphometric evaluation of gastric antral atrophy: Improvement after cure of Helicobacter pylori infection. Am J Gastroenterol 2001:96:3281-7.

31 Sung JJY, Lin S-R, Ching JYL, Zhou L-Y, To KF, Wang R-T, et al. Atrophy and intestinal metaplasia one year after cure of $\mathrm{H}$. pylori infection: A prospective, randomized study. Gastroenterology 2000;119:7-14

32 You W-C, Brown LM, Zhang L, Li J-Y, Jin M-L, Chang Y-S, et al. Randomized double-blind factorial trial of three treatments to reduce the prevalence of precancerous gastric lesions. J Nat/ Cancer Inst 2006.98:974-83.

33 Zhou L, Sung JJ, Lin S, Jin Z, Ding S, Huang X, et al. A five-year follow-up study on the pathological changes of gastric mucosa after $\mathrm{H}$. pylori eradication. Chin Med J 2003;116:11-4

34 Zhou L. Eight-year follow-up study on the morbidity of gastric cancer and the pathological changes of gastric mucosa after H. pylori eradication. Gastroenterology 2005;128(suppl 2):A16.

35 Correa P, Fontham ETH, Bravo JC, Bravo LE, Ruiz B, Zarama G, et al. Chemoprevention of gastric dysplasia: Randomized trial of antioxidant supplements and anti-Helicobacter pylori therapy. Reply. J Natl Cancer Inst 2001;93:559-60.

36 Take S, Mizuno M, Ishiki K, Nagahara Y, Yoshida T, Yokota K, et al. The effect of eradicating Helicobacter pylori on the development of gastric cancer in patients with peptic ucer disease. Am J Gastroenterol 2005:100:1037-42.

37 Hamajima N, Matuo K, Watanabe Y, Suzuki T, Nakamura T, Matsuura A, et al. A pilot study to evaluate stomach cancer risk reduction by Helicobacter pylori eradication. $A m \mathrm{~J}$ Gastroenterol 2002;97:764-5.

38 Hsu P-I, Lai K-H, Hsu P-N, Lo G-H, Yu H-C, Chen W-C, et al. Helicobacter pylori infection and the risk of gastric cancer. Am J Gastroenterol 2007;102:725-30.

39 Juibari M, Moayyedi R, Gholampour M, Bijarchi R, Peter K, Koucharian C, et al. Risk of precancerous pathologic changes in the stomach after appropriate eradication of Helicobacter pylori: A multi-centric study from a developing country. Gut 2003;52(suppl $\mathrm{VI}): \mathrm{A} 148$

40 Ohkusa T, Fujiki K, Takashimuzu I, Kumagai J, Tanizawa T, Eishi Y, et al. Improvement in atrophic gastritis and intestinal metaplasia in patients in whom Helicobacter pylori was eradicated. Ann Intern Med 2001;134:380-6.
41 Kamangar F, Dawsey SM, Blaser MJ, Perez-Perez GI, Pietinen P, Newschaffer CJ, et al. Opposing risks of gastric cardia and noncardia gastric adenocarcinomas associated with Helicobacter pylori seropositivity. J Natl Cancer Inst 2006;98:1445-52.

42 Harvey RF, Lane JA, Murray LJ, Harvey IM, Donovan JL, Nair P. Randomised controlled trial of effects of Helicobacter pylori infection and its eradication on heartburn and gastro-oesophageal reflux: Bristol Helicobacter project. Br Med J 2004:328:1417-20.

43 Moayyedi P, Feltbower R, Brown J, Mason S, Mason J, Nathan J, et al. Effect of population screening and treatment for Helicobacter pylori on dyspepsia and quality of life in the community: A randomised controlled trial. Lancet 2000;355:1665-9.

44 Wildner-Christensen M, Moller Hansen J, Schaffalitzky De Muckadell O. Rates of dyspepsia one year after Helicobacter pylori screening and eradication in a Danish population. Gastroenterology 2003;125:372-9.

45 Fischbach LA, Correa P, Ramirez H, Realpe JL, Collazos T, Ruiz B, et al. Anti-inflammatory and tissue-protectant drug effects: Results from a randomized placebo-controlled trial of gastritis patients at high risk for gastric cancer. Aliment Pharmacol Ther 2001;15:831-41.

46 Miehlke S, Kirsch C, Dragosics B, Gschwantler M, Oberhuber G, Antos D, et al. Helicobacter pylori and gastric cancer: Current status of the Austrian Czech German gastric cancer prevention trial (PRISMA-Study). World J Gastroenterol 2001;7:243-7.

47 Ford AC, Forman D, Bailey AG, Axon ATR, Moayyedi P. A community screening program for Helicobacter pylori saves money: Ten-year follow-up of a randomised controlled trial. Gastroenterology 2005;129:1910-7.

48 Lane JA, Murray LJ, Noble S, Egger M, Harvey IM, Donovan JL, et al. Impact of Helicobacter pylori eradication on dyspepsia, health resource use, and quality of life in the Bristol Helicobacter project: Randomised controlled trial. BMJ 2006;332:199-202.

49 Mason J, Axon ATR, Forman D, Duffett S, Drummond M, Crocombe W, et al. The cost-effectiveness of population Helicobacter pylori screening and treatment: A Markov model using economic data from a randomised controlled trial. Aliment Pharmacol Ther 2002;16:559-68.

50 Imanzadeh F, Sayyari AA, Akbari MR. Histopathology of the stomach mucosa after treatment for Helicobacter pylori: A multi-centric study. Gut 2004:53(suppl VI):A292.

51 Fukase K, Kato M, Kikuchi S, Inoue K, Uemura N, Okamoto S, et al. Effect of eradication of Helicobacter pylori on incidence of metachronous gastric carcinoma after endoscopic resection of early gastric cancer: An open-label, randomised controlled trial. Lancet 2008;372:392-7.

52 Choi J, Kim SG, Yoon H, Im JP, Kim JS, Kim WH, et al. Eradication of Helicobacter pylori after endoscopic resection of gastric tumors does not reduce incidence of metachronous gastric carcinoma. Clin Gastroenterol Hepatol 2014:12:793-800.

53 Fischbach LA, Bravo LE, Zarama GR, Bravo JC, Ojha PR, Priest EL, et al. A randomized clinical trial to determine the efficacy of regimens containing clarithromycin, metronidazole, and amoxicillin among histologic subgroups for Helicobacter pylori in a developing country. Helicobacter 2009;14:100-8.

54 Gail MH, You WC, Chang YS, Zhang L, Blot WJ, Brown LM, et al. Factorial trial of three interventions to reduce the progression of precancerous gastric lesions in Shandong, China: Design issues and initial data. Control Clin Trials 1998;19:352-69.

55 Bazzoli F, Zagari RM, Fossi S, Pozzato P, Alampi G, Simoni P, et al. Short-term low-dose triple therapy for the eradication of Helicobacter pylori. Eur J Gastroenterol Hepatol 1994;6:773-7.

56 Correa P, Cuello C, Dugue E, Burbano LC, Garcia FT, Bolanos O, et al. Gastric cancer in Colombia III: Natural history of precursor lesions. J Natl Cancer Inst 1976;57:1027-35.

57 Lee Y-C, Chen TH-H, Chiu H-M, Shun C-T, Chiang H, Liu T-Y, et al. The benefit of mass eradication of Helicobacter pylori infection: A community-based study of gastric cancer prevention. Gut 2013;62:676-82.

58 Areia M, Carvalho R, Cadime AT, Rocha Goncalves F, Dinis-Ribeiro M. Screening for gastric cancer and surveillance of premalignant lesions: A systematic review of cost-effectiveness studies. Helicobacter 2013:18:325-37.

59 Harvey RF, Lane JA, Nair P, Egger M, Harvey I, Donovan J, et al. Clinical trial: Prolonged beneficial effect of Helicobacter pylori eradication on dyspepsia consultations-The Bristol Helicobacter Project. Aliment Pharmacol Ther 2010;32:394-400

60 Talley NJ, Fock KM, Moayyedi P. Gastric Cancer Consensus conference recommends Helicobacter pylori screening and treatment in asymptomatic persons from high-risk populations to prevent gastric cancer. Am J Gastroenterol 2008;103:510-4.

Accepted: 30 April 2014

\section{Cite this as: BMJ 2014;348:g3174}

This is an Open Access article distributed in accordance with the Creative Commons Attribution Non Commercial (CC BY-NC 3.0) license, which permits others to distribute, remix, adapt, build upon this work non-commercially, and license their derivative works on different terms, provided the original work is properly cited and the use is non-commercial. See: http://creativecommons.org/licenses/by-nc/3.0/. 


\section{Tables}

\begin{tabular}{|c|c|c|c|c|c|c|c|c|c|c|}
\hline Study & Location & $\begin{array}{c}\text { Method to } \\
\text { confirm } H \\
\text { pylori } \\
\text { infection }\end{array}$ & $\begin{array}{c}\text { Sample } \\
\text { size (No } \\
\text { receiving } H \\
\text { pylori } \\
\text { eradication } \\
\text { therapy) }\end{array}$ & $\begin{array}{l}\text { Characteristics } \\
\text { of participants }\end{array}$ & $\begin{array}{c}\% \text { with } \\
\text { pre-neoplastic } \\
\text { lesions* at } \\
\text { baseline }\end{array}$ & $\begin{array}{l}H \text { pylori } \\
\text { eradication } \\
\text { therapy } \\
\text { regimen }\end{array}$ & $\begin{array}{c}\text { Eradication } \\
\text { rate }(\%) \dagger\end{array}$ & $\begin{array}{c}\text { Last } \\
\text { point of } \\
\text { follow-up }\end{array}$ & $\begin{array}{l}\text { Method to } \\
\text { detect gastric } \\
\text { cancer cases }\end{array}$ & Methodology \\
\hline $\begin{array}{l}\text { Correa } \\
2000^{22} \\
\text { and } \\
\text { Correa } \\
2001^{35}\end{array}$ & $\begin{array}{c}2 \\
\text { communities } \\
\text { in Narino } \\
\text { Province, } \\
\text { Colombia }\end{array}$ & $\begin{array}{l}\text { Histological } \\
\text { examinationf }\end{array}$ & $852(437)$ & $\begin{array}{c}\text { Mean (range) } \\
\text { age } 51.1(29-69) \\
\text { years, } 46.1 \% \\
\text { men }\end{array}$ & 100 & $\begin{array}{c}\text { Bismuth } \\
\text { subsalicylate } \\
262 \mathrm{mg}, \\
\text { amoxicillin } \\
500 \mathrm{mg}, \\
\text { metronidazole } \\
375 \mathrm{mg} \text { thrice } \\
\text { daily for } 2 \text { weeks }\end{array}$ & 58.0 & 6 years & $\begin{array}{l}\text { Histological } \\
\text { examination } \neq \\
\text { at } 6 \text { years }\end{array}$ & $\begin{array}{l}\text { Method of } \\
\text { randomisation } \\
\text { and } \\
\text { concealment of } \\
\text { allocation } \\
\text { stated. } \\
\text { Unblinded }\end{array}$ \\
\hline $\begin{array}{l}\text { Leung } \\
2004^{28} \\
\text { and } \\
\text { Zhou } \\
2008^{27}\end{array}$ & $\begin{array}{l}11 \text { villages in } \\
\text { Yantai } \\
\text { County, } \\
\text { Shandong } \\
\text { Province, } \\
\text { China }\end{array}$ & $\begin{array}{c}\text { Histological } \\
\text { examination } \\
\text { and rapid } \\
\text { urease } \\
\text { testing } \ddagger\end{array}$ & $\begin{array}{l}\text { Leung: } 587 \\
\quad(295) \\
\text { Zhou: } 552 \\
(276)\end{array}$ & $\begin{array}{c}\text { Mean (range) } \\
\text { age } 52.0(35-75) \\
\text { years, } 47.8 \% \\
\text { men }\end{array}$ & 33.7 & $\begin{array}{l}\text { Omeprazole } \\
20 \mathrm{mg}, \\
\text { amoxicillin } 1 \mathrm{~g}, \\
\text { clarithromycin } \\
500 \mathrm{mg} \text { twice } \\
\text { daily for } 1 \text { week }\end{array}$ & 55.6 & $\begin{array}{l}\text { Leung: } 5 \\
\text { years } \\
\text { Zhou: } 10 \\
\text { years }\end{array}$ & $\begin{array}{l}\text { Histological } \\
\text { examination } \ddagger \\
\text { at } 2,5,8 \text {, and } \\
10 \text { years }\end{array}$ & $\begin{array}{l}\text { Method of } \\
\text { randomisation } \\
\text { and } \\
\text { concealment of } \\
\text { allocation } \\
\text { stated. Double } \\
\text { blind }\end{array}$ \\
\hline $\begin{array}{l}\text { Wong } \\
2004^{24}\end{array}$ & $\begin{array}{l}7 \text { villages in } \\
\text { Changle } \\
\text { County, } \\
\text { Fujian } \\
\text { Province, } \\
\text { China }\end{array}$ & $\begin{array}{l}\text { Histological } \\
\text { examination } \\
\text { and rapid } \\
\text { urease } \\
\text { testing } \ddagger\end{array}$ & $1630(817)$ & $\begin{array}{c}\text { Mean (range) } \\
\text { age } 42.2(35-65) \\
\text { years, } 54.0 \% \\
\text { men }\end{array}$ & 37.7 & $\begin{array}{c}\text { Omeprazole } \\
20 \mathrm{mg}, \\
\text { co-amoxiclav } \\
750 \mathrm{mg}, \\
\text { metronidazole } \\
400 \mathrm{mg} \text { twice } \\
\text { daily for } 2 \text { weeks }\end{array}$ & 83.7 & 7.5 years & $\begin{array}{l}\text { Histological } \\
\text { examinationf } \\
\text { at } 7.5 \text { years or, } \\
\text { if diagnosed } \\
\text { before } 7.5 \\
\text { years, review } \\
\text { of clinical } \\
\text { records and } \\
\text { pathology } \\
\text { specimens by } \\
\text { three blinded } \\
\text { clinicians }\end{array}$ & $\begin{array}{l}\text { Method of } \\
\text { randomisation } \\
\text { and } \\
\text { concealment of } \\
\text { allocation } \\
\text { stated. } \\
\text { Double-blind } \\
\end{array}$ \\
\hline $\begin{array}{l}\text { Saito } \\
2005^{23}\end{array}$ & $\begin{array}{l}145 \text { centres } \\
\text { in Japan }\end{array}$ & Not reported & $692(379)$ & $\begin{array}{l}\text { Mean age not } \\
\text { reported (range } \\
20-59 \text { years), } \\
\text { proportion men } \\
\text { not reported }\end{array}$ & Not reported & $\begin{array}{l}\text { Lansoprazole } \\
30 \mathrm{mg}, \\
\text { amoxicillin } 1.5 \mathrm{~g}, \\
\text { clarithromycin } \\
400 \mathrm{mg} \text { once } \\
\text { daily for } 1 \text { week }\end{array}$ & 74.4 & $\geq 4$ years & $\begin{array}{l}\text { Histological } \\
\text { examination } \neq \\
\text { at } \geq 4 \text { years }\end{array}$ & $\begin{array}{l}\text { Method of } \\
\text { randomisation, } \\
\text { concealment of } \\
\text { allocation, and } \\
\text { blinding not } \\
\text { stated }\end{array}$ \\
\hline $\begin{array}{l}\text { You } \\
2006^{32} \\
\text { and Ma } \\
2012^{26}\end{array}$ & $\begin{array}{l}13 \text { villages in } \\
\text { Linqu } \\
\text { County, } \\
\text { Shandong } \\
\text { Province, } \\
\text { China }\end{array}$ & $\begin{array}{l}\text { Serological } \\
\text { testing }\end{array}$ & $2258(1130)$ & $\begin{array}{c}\text { Mean (range) } \\
\text { age } 46.8(35-64) \\
\text { years, } 50.0 \% \\
\text { men }\end{array}$ & 64.0 & $\begin{array}{c}\text { Omeprazole } \\
20 \mathrm{mg} \text { and } \\
\text { amoxicillin } 1 \mathrm{~g} \\
\text { twice daily for } 2 \\
\text { weeks }\end{array}$ & 73.2 & $\begin{array}{l}14.7 \\
\text { years }\end{array}$ & $\begin{array}{l}\text { Histological } \\
\text { examinationł, } \\
\text { clinical, } \\
\text { laboratory, or } \\
\text { pathological } \\
\text { data }\end{array}$ & $\begin{array}{l}\text { Method of } \\
\text { randomisation } \\
\text { and } \\
\text { concealment of } \\
\text { allocation } \\
\text { stated. Double } \\
\text { blind }\end{array}$ \\
\hline $\begin{array}{l}\text { Wong } \\
2012^{25}\end{array}$ & $\begin{array}{l}12 \text { villages in } \\
\text { Linqu } \\
\text { County, } \\
\text { Shandong } \\
\text { Province, } \\
\text { China }\end{array}$ & $\begin{array}{l}{ }^{13} \text { Carbon-urea } \\
\text { breath testing }\end{array}$ & $513(255)$ & $\begin{array}{c}\text { Mean (range) } \\
\text { age } 53.0(35-64) \\
\text { years, } 46.4 \% \\
\text { men }\end{array}$ & 100 & $\begin{array}{l}\text { Omeprazole } \\
20 \mathrm{mg}, \\
\text { amoxicillin } 1 \mathrm{~g}, \\
\text { clarithromycin } \\
500 \mathrm{mg} \text { twice } \\
\text { daily for } 1 \text { week }\end{array}$ & 63.5 & 5 years & $\begin{array}{l}\text { Histological } \\
\text { examination } \neq \\
\text { at } 5 \text { years }\end{array}$ & $\begin{array}{l}\text { Method of } \\
\text { randomisation } \\
\text { and } \\
\text { concealment of } \\
\text { allocation } \\
\text { stated. Double } \\
\text { blind }\end{array}$ \\
\hline
\end{tabular}

*Defined as gastric atrophy, intestinal metaplasia, or dysplasia

†True intention-to-treat analysis, with all drop-outs assumed to have failed eradication therapy.

łExamination or testing of gastric biopsies obtained from upper gastrointestinal endoscopy. 
Table 2| Numbers needed to treat to prevent one case of gastric cancer calculated from lifetime risk of gastric cancer in each country ${ }^{18}$

Country Sex Lifetime risk (\%) Number needed to treat $(95 \% \mathrm{Cl})$

\begin{tabular}{lccc} 
China & Men & 19.5 & $15.1(9.5$ to 102.6$)$ \\
\cline { 2 - 4 } & Women & 12.4 & $23.7(14.9$ to 161.3$)$ \\
\hline \multirow{2}{*}{ Japan } & Men & 19.2 & $15.3(9.6$ to 104.2$)$ \\
\cline { 2 - 4 } & Women & 12.8 & $23.0(14.5$ to 156.3$)$ \\
\hline \multirow{2}{*}{ USA } & Men & 1.8 & $163.4(102.9$ to 1111.1$)$ \\
\cline { 2 - 4 } & Women & 1.2 & $245.1(154.3$ to 1666.7$)$ \\
\hline \multirow{2}{*}{ UK } & Men & 3.1 & $94.9(59.7$ to 645.2$)$ \\
\cline { 2 - 4 } & Women & 1.8 & $163.4(102.9$ to 1111.1$)$ \\
\hline
\end{tabular}


Table 3 | Sensitivity analyses of randomised controlled trials of $\mathbf{H}$ pylori eradication therapy in the prevention of gastric cancer

\begin{tabular}{|c|c|c|c|c|c|c|}
\hline \multirow[b]{2}{*}{ Analysis } & \multirow[b]{2}{*}{$\begin{array}{l}\text { Total } \\
\text { No of } \\
\text { studies }\end{array}$} & \multicolumn{2}{|c|}{$\begin{array}{c}\text { Subjects who received eradication } \\
\text { therapy }\end{array}$} & \multicolumn{2}{|c|}{$\begin{array}{c}\text { Subjects who received placebo or no } \\
\text { treatment }\end{array}$} & \multirow[b]{2}{*}{$\begin{array}{l}\text { Relative risk (95\% } \\
\text { Cl) of gastric } \\
\text { cancer }\end{array}$} \\
\hline & & Total No & $\begin{array}{c}\text { No }(\%) \text { who } \\
\text { developed gastric } \\
\text { cancer }\end{array}$ & Total No & $\begin{array}{c}\text { No }(\%) \text { who } \\
\text { developed gastric } \\
\text { cancer }\end{array}$ & \\
\hline Primary modified intention-to-treat analysis & 6 & 3294 & $51(1.6)$ & 3203 & $76(2.4)$ & $0.66(0.46$ to 0.95$)$ \\
\hline Complete case analysis & 6 & 3073 & $51(1.7)$ & 2965 & $76(2.6)$ & $0.66(0.46$ to 0.94$)$ \\
\hline $\begin{array}{l}\text { Modified intention-to-treat analysis with } \\
\text { Leung } 2004 \text { instead of Zhou } 2008\end{array}$ & 6 & 3313 & $53(1.6)$ & 3219 & $75(2.3)$ & 0.69 (0.49 to 0.98$)$ \\
\hline $\begin{array}{l}\text { Complete case analysis with Leung } 2004 \\
\text { instead of Zhou } 2008\end{array}$ & 6 & 3017 & $53(1.8)$ & 2904 & $75(2.6)$ & 0.69 (0.48 to 0.98$)$ \\
\hline $\begin{array}{l}\text { Modified intention-to-treat analysis including } \\
\text { the celecoxib arms from Wong } 2012\end{array}$ & 6 & 3549 & $54(1.5)$ & 3459 & $78(2.3)$ & $0.69(0.48$ to 0.97$)$ \\
\hline $\begin{array}{l}\text { Modified intention-to-treat analysis assuming } \\
\text { incidence of gastric cancer for missing } \\
\text { participants in both arms same as that } \\
\text { observed in trial control arms }\end{array}$ & 6 & 3294 & $53(1.6)$ & 3203 & $79(2.5)$ & $0.66(0.47$ to 0.94$)$ \\
\hline $\begin{array}{l}\text { Modified intention-to-treat analysis assuming } \\
\text { incidence of gastric cancer for missing } \\
\text { participants in trial treatment arms same as } \\
\text { that observed in the trial control arms, and } \\
\text { no events in missing participants in trial } \\
\text { control arms }\end{array}$ & 6 & 3294 & $53(1.6)$ & 3203 & $76(2.4)$ & 0.69 (0.48 to 0.98$)$ \\
\hline
\end{tabular}


Table 4| Subgroup analyses of randomised controlled trials of $\mathbf{H}$ pylori eradication therapy in the prevention of gastric cancer

\begin{tabular}{|c|c|c|c|c|c|c|}
\hline \multirow[b]{2}{*}{ Analysis } & \multirow{2}{*}{$\begin{array}{c}\text { Total No } \\
\text { of } \\
\text { studies }\end{array}$} & \multicolumn{2}{|c|}{ Subjects who received eradication therapy } & \multicolumn{2}{|c|}{$\begin{array}{l}\text { Subjects who received placebo or no } \\
\text { treatment }\end{array}$} & \multirow[b]{2}{*}{$\begin{array}{l}\text { Relative risk }(95 \% \mathrm{Cl}) \\
\text { of gastric cancer }\end{array}$} \\
\hline & & Total No & $\begin{array}{l}\text { No (\%) who developed } \\
\text { gastric cancer }\end{array}$ & Total No & $\begin{array}{l}\text { No (\%) who developed } \\
\text { gastric cancer }\end{array}$ & \\
\hline \multicolumn{7}{|l|}{$\begin{array}{l}\text { Eradication therapy } \\
\text { used: }\end{array}$} \\
\hline PPI triple therapy & 4 & 1727 & $14(0.8)$ & 1660 & $22(1.3)$ & $0.61(0.31$ to 1.24$)$ \\
\hline Other & 2 & 1567 & $37(2.4)$ & 1543 & $54(3.5)$ & $0.68(0.45$ to 1.03$)$ \\
\hline \multicolumn{7}{|l|}{ Study location: } \\
\hline Far East & 5 & 2857 & $48(1.7)$ & 2788 & $74(2.7)$ & $0.64(0.45$ to 0.92$)$ \\
\hline South America & 1 & 437 & $3(0.7)$ & 415 & $2(0.5)$ & $1.42(0.24$ to 8.48$)$ \\
\hline \multicolumn{7}{|l|}{ Risk of bias: } \\
\hline Low & 3 & 2202 & $44(2.0)$ & 2199 & $64(2.9)$ & $0.68(0.46$ to 0.99$)$ \\
\hline High or unclear & 3 & 1092 & $7(0.6)$ & 1004 & $12(1.2)$ & $0.57(0.21$ to 1.51$)$ \\
\hline
\end{tabular}




\section{Figures}

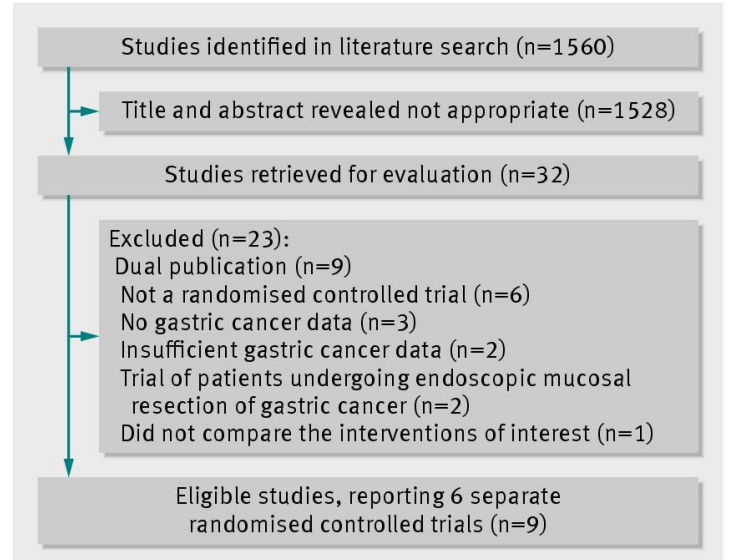

Fig 1 Flow diagram of assessment of studies identified in the systematic review

\begin{tabular}{|c|c|c|c|c|c|c|c|c|}
\hline \multirow{3}{*}{$\begin{array}{l}\text { Study } \\
\text { Correa } 2000\end{array}$} & \multicolumn{2}{|c|}{ No of events/total } & & & & & \multirow[b]{2}{*}{$\begin{array}{c}\text { Weight } \\
\text { (\%) }\end{array}$} & \multirow[b]{2}{*}{$\begin{array}{c}\text { Risk ratio } \\
(95 \% \mathrm{Cl})\end{array}$} \\
\hline & $\begin{array}{c}\text { H pylori } \\
\text { eradication }\end{array}$ & Control & \multicolumn{4}{|c|}{$\begin{array}{c}\text { Risk ratio } \\
(95 \% \mathrm{Cl})\end{array}$} & & \\
\hline & $3 / 437$ & $2 / 415$ & & & & & 4.0 & $1.42(0.24$ to 8.48$)$ \\
\hline Wong 2004 & $7 / 817$ & $11 / 813$ & & & & & 14.2 & $0.63(0.25$ to 1.63$)$ \\
\hline Leung 2004-Zhou 2008 & $8 \quad 2 / 276$ & $7 / 276$ & & & & & 5.2 & $0.29(0.06$ to 1.36$)$ \\
\hline Saito 2005 & $2 / 379$ & $3 / 313$ & & & & & 4.0 & 0.55 (0.09 to 3.27$)$ \\
\hline You 2004-Ma 2012 & $34 / 1130$ & $52 / 1128$ & & & & & 70.2 & $0.65(0.43$ to 1.00$)$ \\
\hline Wong 2012 & $3 / 255$ & $1 / 258$ & & & & & 2.5 & 3.04 (0.32 to 28.99 ) \\
\hline Total & $51 / 3294$ & $76 / 3203$ & & $<$ & & & 100.0 & $0.66(0.46$ to 0.95$)$ \\
\hline \multicolumn{8}{|c|}{ Test for heterogeneity: $\tau^{2}=0.00, \chi^{2}=3.62, \mathrm{df}=5$, } & \\
\hline \multicolumn{3}{|c|}{ Test for overall effect: $z=2.27, P=0.02$} & $\begin{array}{l}\text { Favours } \\
\text { eradicatio }\end{array}$ & & & & & \\
\hline
\end{tabular}

Fig 2 Forest plot of randomised controlled trials of $H$ pylori eradication therapy: effect on subsequent occurrence of gastric cancer 


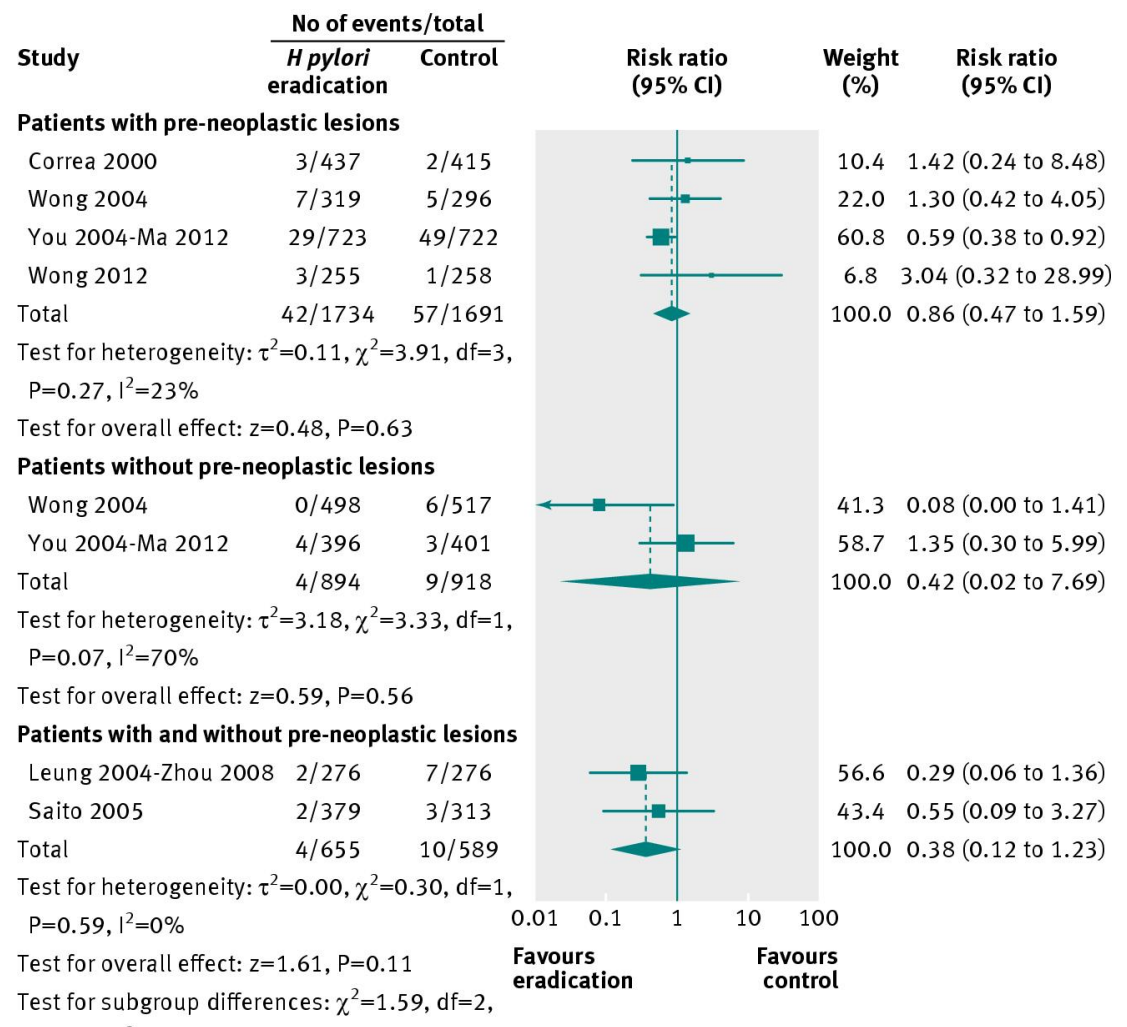

作 $\chi^{2}=1.59, \mathrm{df}=2$

$P=0.45, I^{2}=0 \%$

Fig 3 Forest plot of randomised controlled trials of $\mathrm{H}$ pylori eradication therapy: effect on subsequent occurrence of gastric cancer according to presence or absence of pre-neoplastic lesions at baseline. (You 2006 ${ }^{32}$ and Ma $2012^{26}$ study had missing data concerning presence or absence of pre-neoplastic lesions at baseline for 16 individuals, leading to the loss of one gastric cancer from the analysis)

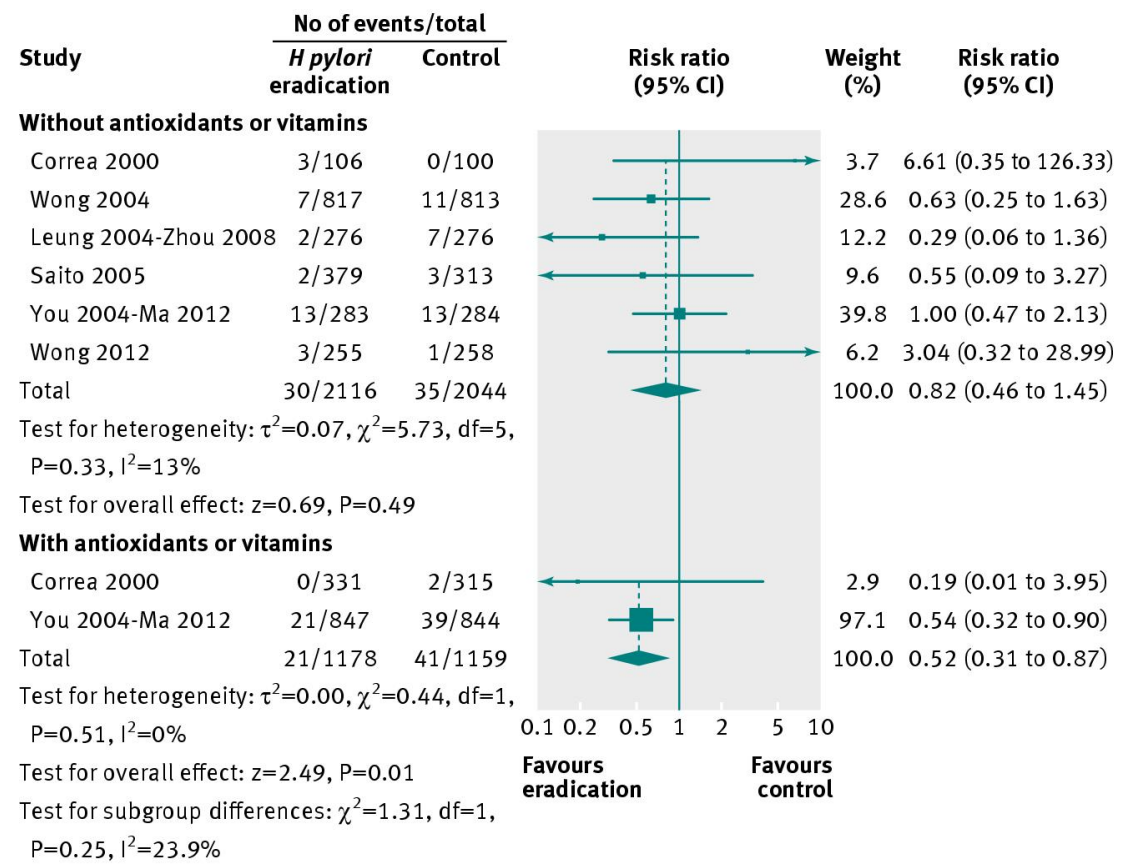

Fig 4 Forest plot of randomised controlled trials of $H$ pylori eradication therapy: effect on subsequent occurrence of gastric cancer according to anti-oxidant or vitamin use 


\begin{tabular}{|c|c|c|c|c|c|c|c|c|}
\hline \multirow{3}{*}{$\begin{array}{l}\text { Study } \\
\text { Leung 2004-Zhou } 2008\end{array}$} & \multicolumn{2}{|c|}{ No of events/total } & & & & & \multirow[b]{2}{*}{$\begin{array}{c}\text { Weight } \\
\text { (\%) }\end{array}$} & \multirow[b]{2}{*}{$\begin{array}{c}\text { Risk ratio } \\
(95 \% \mathrm{Cl})\end{array}$} \\
\hline & $\begin{array}{c}H \text { pylori } \\
\text { eradication }\end{array}$ & Control & & \multicolumn{3}{|c|}{$\begin{array}{c}\text { Risk ratio } \\
(95 \% \mathrm{Cl})\end{array}$} & & \\
\hline & $84 / 295$ & $6 / 292$ & & & & & 16.7 & $0.66(0.19$ to 2.31$)$ \\
\hline Wong 2004 & $3 / 817$ & $6 / 813$ & & & & & 13.8 & $0.50(0.12$ to 1.98$)$ \\
\hline You 2004-Ma 2012 & $17 / 1130$ & $24 / 1128$ & & & & & 69.5 & $0.71(0.38$ to 1.31$)$ \\
\hline Total & $24 / 2242$ & $36 / 2233$ & & & & & 100.0 & $0.67(0.40$ to 1.11$)$ \\
\hline \multicolumn{9}{|c|}{ Test for heterogeneity: $\tau^{2}=0.00, \chi^{2}=0.21, \mathrm{df}=2$} \\
\hline \multicolumn{3}{|c|}{ Test for overall effect: $z=1.55, P=0.12$} & $\begin{array}{l}\text { Favours } \\
\text { eradicati }\end{array}$ & & & $\begin{array}{l}\text { Favo } \\
\text { cont }\end{array}$ & & \\
\hline
\end{tabular}

Fig 5 Forest plot of randomised controlled trials of $H$ pylori eradication therapy: effect on subsequent mortality from gastric cancer

\begin{tabular}{|c|c|c|c|c|c|c|c|c|}
\hline \multirow{3}{*}{$\begin{array}{l}\text { Study } \\
\text { Correa } 2000\end{array}$} & \multicolumn{2}{|c|}{ No of events/total } & & & & & \multirow[b]{2}{*}{$\begin{array}{c}\text { Weight } \\
\text { (\%) }\end{array}$} & \multirow[b]{2}{*}{$\begin{array}{c}\text { Risk ratio } \\
(95 \% \mathrm{Cl})\end{array}$} \\
\hline & $\begin{array}{c}\text { H pylori } \\
\text { eradication }\end{array}$ & Control & \multicolumn{4}{|c|}{$\begin{array}{c}\text { Risk ratio } \\
(95 \% \mathrm{Cl})\end{array}$} & & \\
\hline & $12 / 437$ & $6 / 415$ & & & & & 5.7 & $1.90(0.72$ to 5.01$)$ \\
\hline Wong 2004 & $22 / 817$ & $23 / 813$ & & & & & 15.4 & 0.95 (0.53 to 1.69$)$ \\
\hline Wong 2012 & $1 / 255$ & $4 / 258$ & & & & & 1.2 & 0.25 (0.03 to 2.25$)$ \\
\hline You 2004-Ma 2012 & $157 / 1130$ & $142 / 1128$ & & & & & 77.7 & $1.10(0.89$ to 1.36$)$ \\
\hline Total & $192 / 2639$ & $175 / 2614$ & & & - & & 100.0 & 1.09 (0.86 to 1.38$)$ \\
\hline \multicolumn{9}{|c|}{ Test for heterogeneity: $\tau^{2}=0.01, \chi^{2}=3.20, \mathrm{df}=3$, } \\
\hline \multicolumn{3}{|c|}{$P=0.36, I^{2}=6 \%$} & $0.10 .2 \quad 0$ & 0.5 & 2 & 5 & 10 & \\
\hline \multicolumn{3}{|c|}{ Test for overall effect: $z=0.75, P=0.45$} & $\begin{array}{l}\text { Favours } \\
\text { eradicatio }\end{array}$ & & & & & \\
\hline
\end{tabular}

Fig 6 Forest plot of randomised controlled trials of $H$ pylori eradication therapy: effect on subsequent all cause mortality 